\title{
FORECASTING THE RETURN OF THE LOAN PORTFOLIO ON THE BASIS OF MARKOV MODEL
}

\author{
G.A. Timofeeva, Ural State University of Railway Transport, Ekaterinburg, \\ Russian Federation, Gtimofeeva@usurt.ru
}

\begin{abstract}
We consider the problem of mathematical modelling of flows of loan portfolio payments. We assume that the change in the quality of each loan is described by a simple Markov chain with a finite number of states. In this case, the flow of loan payments is a random process, which depends on the Markov chain. On the basis of the proposed model and known relations of the stochastic systems theory, we describe the expected flows of payments of the entire loan portfolio and construct a method to forecast the expected return (net present value) of the portfolio. We analyze an accuracy of the obtained model and a sensitivity of net present value of the portfolio to a change in the transition probabilities in the Markov chain.
\end{abstract}

Keywords: payment flows; Markov chain; loan portfolio; forecasting.

\section{Introduction}

Multistage systems, which are associated with the Markov chains, describe a wide range of mechanical, physical and economic processes. In particular, the dynamics of the loan portfolio structure can be investigated within the framework of the model of a simple Markov chain.

In order to forecast the quality of the loan portfolio, the use of migration factors (migration matrix) was proposed in [1]. In this document, as well as in the subsequent works of this direction, $[2,3]$ the period of the quality change is 1 year, and there are groups by the value of the loan rating, therefore the quality of the loan is determined by the group associated with the loan. The loan rating levels are denoted by the letters $A A A$, $A A$ etc. up to $D$ (default), and the matrix of transitions (migration) is calculated on the basis of long-term market observations [2].

This approach is mathematically formalized as a Markov chain with a discrete time and a finite number of states. Herewith, the matrix of transition probabilities in the Markov chain is assumed to be constant and is taken equal to the migration matrix. A significant number of papers are devoted to methods of estimating the migration matrix [4] and conducting their comparative analysis [5].

Criteria for checking the adequacy of the stationary model of the Markov chain by statistical data on the number of transitions are formulated in the classical paper [6]. Many authors note that the assumptions of standard model in describing changes in the quality of loans are not fully satisfied [7], and propose to use hidden Markov chains [8], double Markov chains [9], Markov chains with variable probabilities [7] and to take into account the uncertainty of the transition matrix coefficients [10], etc.

Nevertheless, bank analysts often use the classical model of Markov chain for forecasting loan risks, but not the complicated versions of the model. Markov random process in the form of a simple chain is used in the papers [4,11] for modelling the behaviour of bank borrowers. In the paper [4], the loans are splitted into groups depending on the availability and the terms of debt on the loans. Nowadays, Markov model of the loan 
portfolio with the distribution of loans by groups depending on the availability and terms of the debt is used to analyze portfolios of consumer loans, and migration analysis has entered in banking practice (including Russian one) as a tool to forecast the loan risk [12] and determine the level of required reserves $[12,13]$. Both these indicators are closely related to the portfolio structure, that is, to the probability that a loan is in a particular group of loans. By most analysts, the risk of the loan portfolio is assumed to be equal to the expected share of problem loans over a fixed period of time. This indicator is calculated directly on the basis of the Markov model. It provides a wide application of the model by foreign and Russian researchers.

Bank lending to individuals and legal entities can be considered as an investment process, the parameters of which are determined by the conditions of the loan, including the interest rate on loans, conditions for the approval of applications, etc. In financial analysis, the return evaluation of investment projects is based on the analysis of payment flows and their quantitative indicators [14], one of which is the net present value of the project $(N P V)$.

In the papers of Western analysts, forecasting the assets return using the Markov model is based on a combination of migration analysis and a model of changing the value of a financial asset in the form of a Wiener process [1,15]. Such models are used to analyse lending to firms, i.e. legal entities in the terminology of the Bank of Russia.

As opposed to these papers, we consider a specific flow of payments generated by the portfolio of homogeneous consumer loans under the following assumptions. First, the change in state (by the presence and duration of overdue payments) of a randomly chosen loan is described as a Markov chain. Second, payments under the contract are calculated by the formula of annuity payments and are completely determined by a sequence of the Markov chain states.

\section{The Problem Statement}

Suppose that a state of the investment project is described by the Markov process with discrete time $\xi_{t}=\{\xi(1), \ldots, \xi(t)\}$. We assume that return (cost) $A\left(t, \xi_{t}\right)$ of the project at time $t$ is determined by a random process $\xi_{t}$. Amount of initial investment $A(0)$ is assumed to be given and negative (investment in the project). The positive value of $A\left(t, \xi_{t}\right)$ means profit received in the period $t$, and negative value means costs.

In the financial analysis, one of the characteristics of income from investment project for the period $[0 ; T]$ is a net present value of the project $(N P V(T))$ calculated by the following formula [14]:

$$
N P V(T)=N P V\left(T, \xi_{T}\right)=A(0)+\sum_{t=1}^{T} \frac{A\left(t, \xi_{t}\right)}{(1+r)^{t}},
$$

where $r$ is a discount factor in one step. A risk-free interest rate for a single period of time is taken as a discount factor. In the formula (1), it is assumed that the risk-free interest rate $r$ is constant, although in reality this parameter can change depending on the time period.

In order to describe dynamics of the loan portfolio structure and risk assessment, the mathematical model of a simple Markov chain is used [10]. The portfolio is divided into $k$ groups, for example: 
1) loans without overdue debts, including new ones;

2) loans having overdue up to 30 days;

3) loans having overdue from 31 to 60 days;

4) problem loans (i.e., having overdue more than 60 days);

5) repaid loans.

The group "repaid loans" is introduced to complete the description of the transitions.

Note that modelling within the framework of the Markov chain assumes that any "randomly chosen" credit passes from one group to another in a random way in accordance with the given probabilities $p_{i j}$.

Let us consider the case when payments are described by a dynamical system depending on a simple Markov chain $\xi(t)$. Let $\xi_{t}$ be a Markov chain with $k$ possible states. A probability that the system is in the $i$-th state at time $t$ is denoted by $x_{i}(t)$. Let $\left\{e_{1}, \ldots, e_{k}\right\}$ be a unit basis in $\mathbb{R}^{k}$. If the chain $\xi_{t}$ is in the $i$-th state at time $t$, then $\xi(t)=e_{i}$. Consequently, the probabilities of states can be written as

$$
x_{i}(t)=\mathcal{P}\left\{\xi(t)=e_{i}\right\}, \quad i=1, \ldots, k .
$$

Here and hereinafter we let $\mathcal{P}(A)$ be a probability of the event $A$, and $E(\zeta)$ be an average of distribution of a variate $\zeta$.

Denote by $p_{i j}(t)$ a probability of the object transition from the state $S_{i}$ at time $t$ to the state $S_{j}$ in one step

$$
p_{i j}(t)=\mathcal{P}\left\{\xi(t+1)=e_{j} \mid \xi(t)=e_{i}\right\}
$$

We assume that these probabilities are constant, i.e. $p_{i j}(t) \equiv p_{i j}, i=1, \ldots, k, j=1, \ldots, k$.

Denote the state probability vector by $x(t)=\left\{x_{1}(t), \ldots, x_{k}(t)\right\}^{\top}$, where ${ }^{\top}$ is the transpose sign, and $(k \times k)$-matrix of transition probabilities by $P=\left\{p_{i j}\right\}$. Note that $x(t)=E(\xi(t))$, where $E$ is an average of distribution sign.

Dynamics of the probabilities of the Markov chain states can be written in the form:

$$
x(t+1)=P^{\top} x(t), \quad t=0,1, \ldots, T, \quad x(0) \text { is given } .
$$

The matrix of transition probabilities $P$ is estimated on the basis of statistical data on the number of transitions.

A feature of the functioning of many technical and economic systems that depend on the object state (described by a simple Markov chain) is the following. The output of the system at time $t+1$ depends not only on the current state of the system, but also on its previous state. For a discrete process such dependence can be written in the following form:

$$
A(t+1, \xi(t), \xi(t+1))=c_{i j} \text {, if }\left\{\xi(t)=e_{i} \wedge \xi(t+1)=e_{j}\right\} .
$$

Let $C$ be a matrix of values $\left\{c_{i j}\right\}$. Then the equality (4) is written in the form

$$
A\left(t+1, \xi_{t+1}\right)=\xi(t)^{\top} C \xi(t+1) .
$$


Our goal is to describe mathematically the flows of the loan portfolio payments in the form of a Markov process with discrete time and to obtain an algorithm for estimating the expected income (net present value).

The article considers a portfolio of homogeneous loans issued in one period, loan agreements are based on an annuity payment scheme. We assume that the model of the Markov chain with constant transition probabilities adequately reflects a change in structure of the credit portfolio. We do not take into account the incompleteness of information on transition probabilities, as well as the changes in transition probabilities due to a change in situation on the market, because these issues are beyond the scope of this study.

\section{Multi-Step Model of Payment Flows}

In order to calculate $N P V(T)$ we consider a random process $B\left(t, \xi_{t}\right)$ connected with the initial one $A\left(t, \xi_{t}\right)$ by the following rule:

$$
B\left(t+1, \xi_{t+1}\right)=B\left(t, \xi_{t}\right)+a(t+1) A\left(t+1, \xi_{t+1}\right), t=1, \ldots, T, \quad B(0)=A(0) .
$$

$N P V(T)=B\left(T, \xi_{t}\right)$, where $B\left(T, \xi_{t}\right)$ is determined by the equation (6) for

$$
a(t+1)=\frac{a(t)}{1+r(t)}, \quad a(0)=1 .
$$

The problem of estimating the net present value of the project is a special case of a more general problem. If we consider the general problem of estimating the multistep system dynamics (6), depending on the simple Markov chain $\xi_{t}$, then the process $B\left(t, \xi_{t}\right)$ takes its values in the space $R^{m}$.

The equation (6) for this case takes the form:

$$
B\left(t+1, \xi_{t+1}\right)=B\left(t, \xi_{t}\right)+a(t) \xi(t)^{\top} C \xi(t+1), t=1, \ldots, T,
$$

where $\xi_{t}$ is a discrete Markov chain which dynamics is given by the transition probabilities (2) and the initial probability distribution $x(0)$.

The amount of payment under the contract $A\left(t, \xi_{t}\right)$ for a particular loan at time $t$ depends on the residual amount of the principal debt under the contract $D(t)$, as well as on the groups where the transition will take place.

In turn, the residual amount of the debt $D(t+1)$ at time $t+1$ is determined by the amount of debt at time $t$, the terms of the contract and the amount of payments in the period $(t ; t+1]$.

Consequently, for a particular loan, $N P V(T)=B\left(T, \xi_{T}\right)$ is a random value and is described by the stochastic equation (8), if the random process $\xi_{t}$ satisfies the equation (2).

Suppose that the loans are issued on the basis of the annuity schedule of payments, that is, monthly in accordance with the contract the same sum $d=k_{b} D(0)$ should be paid, the coefficient $k_{b}$ is calculated by the formula:

$$
k_{b}=\frac{b(1+b)^{\tau}}{(1+b)^{\tau}-1}
$$

where $b$ is monthly interest rate on the loan, $\tau$ is a term of the contract in months. 
During each month, a contract, described as the Markov chain $\xi(t)$, either remains in its own group, or goes into another one. At the same time, the amount of principal debt $D(t)=D\left(t, \xi_{t}\right)$ depends on the volume and timeliness of the previous payments on the loan, that is, the amount depends on the loan amount $D(0)$ and the entire pre-history $\xi_{t}$. Let us describe the payments flow within the framework of the accepted symbols.

If the annuity payment under the agreement is paid timely, then

1) amount of payment received by the bank is $A\left(t+1, \xi_{t+1}\right)=d=k_{b} D(0)$;

2) amount of debt under the contract is reduced, while interest for 1 period is paid:

$$
D\left(t+1, \xi_{t+1}\right)=D\left(t, \xi_{t}\right)(1+b)-A\left(t+1, \xi_{t+1}\right) ;
$$

3) group number (for the 1st group - the 3rd group) does not change.

If the annuity payment under the agreement was not paid timely, then:

1) bank does not receive anything: $A\left(t+1, \xi_{t+1}\right)=0$;

2) amount is increased, because interest is accrued on this amount for one month. Let us take into account the amount of interest in the total amount of the loan debt, without distinguishing interest and principal amount of debt:

$$
D\left(t+1, \xi_{t+1}\right)=D\left(t, \xi_{t}\right)(1+b)
$$

3) the group number (for the 1st group - the 3rd group) is increased by 1, number of the problematic loans group does not change.

If the borrower has repaid the entire debt, then

1) amount of payment received by the bank is $A\left(t+1, \xi_{t+1}\right)=(1+b) D\left(t, \xi_{t}\right)$;

2) debt amount becomes zero: $D\left(t+1, \xi_{t}+1\right)=0$;

3) loan passes in the last group "of the repaid loans".

For example, if the debt for 2 months (after the missed payment) is repaid, then the group number is reduced and the amount of payment received by the bank is $2 d$. Also, a reduction of the group number by 2 means that the repaid amount of payment is $3 d$, etc.

In this article, we do not consider the possibility of partial early repayment of principal debt under the loan, which can also be taken into account within the framework of the proposed probabilistic model.

The amounts of payments under the contract $A\left(t, \xi_{t}\right)$ present the flow of payments. The described flow of payments can be written in the form (5). For the considered division into groups, the flow has the following form:

$$
A\left(t+1, \xi_{t+1}\right)=\xi(t)^{\top}\left(d \cdot C_{1}+(1+b) D\left(t, \xi_{t}\right) C_{2}\right) \xi(t+1), \quad t=0,1, \ldots,
$$

where

$$
C_{1}=\left(\begin{array}{ccccc}
1 & 0 & 0 & 0 & 0 \\
2 & 1 & 0 & 0 & 0 \\
3 & 2 & 1 & 0 & 0 \\
4 & 3 & 2 & 0 & 0 \\
0 & 0 & 0 & 0 & 0
\end{array}\right), \quad C_{2}=\left(\begin{array}{ccccc}
0 & 0 & 0 & 0 & 1 \\
0 & 0 & 0 & 0 & 1 \\
0 & 0 & 0 & 0 & 1 \\
0 & 0 & 0 & 0 & 1 \\
0 & 0 & 0 & 0 & 0
\end{array}\right)
$$


The change in the amount of debt under the contract $D\left(t, \xi_{t}\right)$ also depends on the groups where the transition occurs and can be described within the framework of a multistep Markov process of the form (8), depending on a simple chain $\xi_{t}$ :

$$
D\left(t+1, \xi_{t+1}\right)=(1+b) D\left(t, \xi_{t}\right)-\xi(t)^{\top}\left(d \cdot C_{1}+(1+b) D\left(t, \xi_{t}\right) C_{2}\right) \xi(t+1),
$$

$D(0)$ is given. The process stops if there is a transition to the absorbing state (for the considered scheme - in the 5th group of loans).

Therefore, the net present value of one loan contract is determined from the difference equations (8), (10) - (11) and depends on the Markov chain $\xi_{T}$.

In order to calculate the expected return of the portfolio $\overline{N P V}(T)$, it is necessary to analyze the mathematical expectation $E\left(B\left(T, \xi_{T}\right)\right)$, because the number of loans is high, and we assume that payments under the loans (or delays in payments) occur independently. The initial probability distribution $x(0)$ of the Markov chain is set and determined by the ratio of loans groups in the portfolio at the beginning of the period.

If the matrix of transition probabilities is given, then the expected net present value of the portfolio $\overline{N P V}(T)=E\left(B\left(T, \xi_{T}\right)\right)$ is determined based on the traditional approach to calculate the statistical moments of a multistage system. In many cases, the matrix of transition probabilities $P$ is not exactly given in the description of the Markov chain dynamics (2). Herewith, in order to solve the problem of estimation of an average expected return of the portfolio, the methods and algorithms of the theory of dynamic systems estimation under incomplete information should be used [16].

\section{Difference Equations for Expected Portfolio Return}

Consider the relations for calculating the mathematical expectation $E\left(B\left(t, \xi_{t}\right)\right)$. In accordance with the stochastic equation, the return value under the contract $B\left(t, \xi_{t}\right)$ depends on flow of payments $A\left(t, \xi_{t}\right)$, which is determined by the initial sum $D(0)$ and the stochastic difference equations (10) - (11).

Denote the conditional mathematical expectations by

$$
E\left(A(t) \mid \xi(t)=e_{i}\right)=A_{i}(t), \quad E\left(D(t) \mid \xi(t)=e_{i}\right)=D_{i}(t) .
$$

We consider a portfolio including loans of one generation (issued in one month) and for about the same amount. Let $\bar{D}(0)$ be an amount of all loans issued. At the initial moment, all loans are new. Therefore, they belong to the first group of loans and $\xi(0)=e_{1}$.

Suppose that we consider the portfolio as a whole. Then, the accepted notations imply that $A_{i}(t+1)$ is the expected amount of payments for the period $t \rightarrow t+1$, which comes from loans that turn out to be at $i$-th group at the time $t+1$. Similarly, $D_{i}(t+1)$ is the amount of debt at time $t+1$ for the $i$-th group of loans.

The difference equations of conditional ones for the mathematical expectations $A_{i}(t), D_{i}(t)$ are obtained from the linear equation on the basis of a general approach to the description of the moments of a stochastic linear dynamical system that depends on the Markov chain [17].

The equation (10) and the form of the matrix $C_{2}$ imply that the expected amount of payments on loans that turn out to be in the $j$-th group $(j=1, \ldots, 4)$ is

$$
A_{j}(t+1)=d \sum_{i} c_{i j}^{(1)} p_{i j} x_{i}(t)
$$


where $d=k_{b} D(0), k_{b}$ is an annuity payment coefficient, which is determined by the interest rate on the loan $b$ by the formula (9), $x_{i}$ is an expected share of loans in the $i$-th group at time $t$. Dynamics of portfolio shares is described by the equation (3).

Let us write, for example, the expected amount of payments for loans that turn to be in the 1st group at the time $t+1$. The equation (12) implies that the expected amount of payments for the previous month is

$$
A_{1}(t+1)=d\left(p_{11} x_{1}(t)+2 p_{21} x_{2}(t)+3 p_{31} x_{3}(t)+4 p_{41} x_{4}(t)\right) .
$$

The expected payment on the loans transferred to the group of repaid loans is

$$
A_{5}(t+1)=(1+b) \sum_{i=1}^{4} D_{i}(t) p_{i 5}
$$

From the equation (11), we obtain the ratios for the amounts of debt under contracts in the $j$-th group $(j=1, \ldots, 4)$ for the period $t+1$

$$
D_{j}(t+1)=\sum_{i=1}^{4}\left[(1+b) D_{i}(t)-d c_{i j}^{(1)} x_{i}(t)\right] p_{i j}, \quad j=1, \ldots, 4 .
$$

The amount of debt under contracts of the 5th group (repaid loans) is always zero: $D_{5}(t) \equiv 0$.

Taking into account the formula of repeated mathematical expectation, the total payments on the portfolio are

$$
\bar{A}(t)=E\left(A(t, \xi(t))=E\left(E\left\{A(t, \xi(t)) \mid \xi(t)=e_{i}\right\}\right)=\sum_{i=1}^{5} A_{i}(t) x_{i}(t) .\right.
$$

The amount of debt (taking into account the interest) is found from the relation

$$
\bar{D}(t)=E\left(E\left\{D(t, \xi(t)) \mid \xi(t)=e_{i}\right\}\right)=\sum_{i=1}^{5} D_{i}(t) x_{i}(t)
$$

where $D_{i}(t)$ satisfy the equations $(14)$.

Therefore, the difference equations (3), (12) - (14) describe flow of payments, change in the amount of debt by groups and change in the number of contracts in groups. For the considered case with five groups of loans, we obtain 15 difference linear equations that describe the dynamics of the portfolio structure, expected amounts of debt and payment flows by groups.

In order to calculate the portfolio return, we summarize the payment flows for all groups in accordance with the equalities (15) and (16). Taking into account the previously obtained equation (6) for the expected net present value of the portfolio, we obtain the linear difference equation for calculating $E(N P V(T))=\bar{B}(T)$, where

$$
\bar{B}(t+1)=\bar{B}(t)+a(t+1) \sum_{i=1}^{5} A_{i}(t+1) x_{i}(t+1), \quad B(0)=-\bar{D}(0), \quad t=0, \ldots, T .
$$


The introduced equations (12) - (14), (17) allow to forecast the risk and return of the portfolio in conditions, when the matrix of transition probabilities $P$ is known.

In the article [18], the flow of payments of the loan portfolio is described in another form, because the authors use the probabilistic model of the loan portfolio, based on the definition of the portfolio shares $\left\{x_{1}^{D}(t), \ldots, x_{k}^{D}(t)\right\}$ by the ratio of the principal debt

$$
x_{i}^{D}=\frac{D_{i}(t)}{D(t)}, \quad D(t)=D_{1}(t)+\ldots+D_{k}(t)
$$

where $D_{i}(t)$ is an amount of the principal debt at time $t$ for loans of the $i$-th group. Herewith, the transition probabilities are calculated on the basis of transitions of principal debt amounts from group to group:

$$
p_{i j}^{D}(t)=\frac{D_{i j}(t)}{D_{i}(t)}
$$

where $D_{i j}(t)$ is an amount of the principal debt for loans transferred from the $i$-th group to the $j$-th for the period $[t, t+1)$.

Some banks use the formulas (18)-(19) in order to forecast dynamics of the portfolio structure. In addition, such determination of the portfolio shares allows simply describe the flow of payments on the loan portfolio by change in portfolio shares determined by the formula (18) [18]. However, the formula (18) does not fully correspond to the classically defined probability of the state $S_{i}$ of the simple Markov chain. Similarly, the formula (19) does not correspond to the classically defined transition probability $p_{i j}$, which is defined as the probability of the "object" transition from the $i$-th group to $j$-th in 1 step.

We use the classical model of the Markov chain and understand "the object" as a randomly chosen loan, which change its quality (a group of loans) randomly, regardless of prehistory. The transition probabilities $p_{i j}$ are determined by the formula (2) and are estimated by the observed frequencies $w_{i j}$, where

$$
w_{i j}(t)=\frac{n_{i j}(t)}{n_{i}(t)}
$$

$n_{i j}(t)$ is a number of objects (loans) that transit from the $i$-th group to $j$-th group for the period $[t, t+1), n_{i}(t)$ is the total number of objects in the $i$-th group at the beginning of the period.

The determination of portfolio shares by the number of loans in each group does not allow to calculate both the principal debt amounts by groups and loan payments directly only on the basis of the transition probabilities matrix. As shown above, in this model, the flows of payments on the portfolio are described in the form of a random process that depends on the Markov chain. Note that even with approximately the same amounts of loan contracts, the dynamics of portfolio shares by the number of loans $x_{i}(t)$ and by amounts of the principal debt $x_{i}^{D}(t)$ are significantly different, because, for example, the principal debt for loans of the first group is reduced at each step while maintaining the number of loans in this group, and the amount of the principal debt in the problem group changes only when the number of loans is changed. 


\section{Calculation of Payment Flows on Real Data}

The question on the accuracy of the presented model deals with the adequacy of the Markov chain model and the accuracy of the transition probabilities estimates, as well as with a correct description of the payments flow, occurs when a loan is transferred from group to group. Above we have assumed that the transfers of loans from a group to a group are described by a model of the simple Markov chain with a constant transition matrix. As we have noted above, the statistical verification of the assumption often does not confirm the hypothesis, and the matrix of transition probabilities is not precisely given. Nevertheless, the analysts use a model of the simple Markov chain in order to forecast the portfolio risk, because the model is quite simple and gives realistic medium-term forecasts.

In the papers $[10,19]$, the methods of forecasting both the portfolio risk (the shares of problem loans) and the level of required reserves, taking into account the incompleteness of information on transition probabilities, were proposed.

The first method is based on the use of statistical estimates of the probabilities by the observed frequencies. The method consists of constructing confidence estimates for the risk based on confidence estimates of the transition probabilities or using simulation modelling. The simulation method can also be used to estimate the expected portfolio return on the basis of the obtained relations (12) - (14), (17) in order to forecast the flow of payments for a given transition matrix.

The second method describes the incompleteness of information in the dynamic system (3) within the framework of the theory of control and observation under conditions of uncertainty [16]. We assume that information on the matrix of transition probabilities $P$ consists in the given set of possible values $P \in \mathbb{P}$, where $\mathbb{P}$ is a set of admissible values of the matrix elements $\left\{p_{i j}\right\}$ in the space with corresponding dimension taking into account the restrictions on the transition probabilities:

$$
p_{i 1}+\ldots+p_{i 5}=1, \quad p_{i j} \geq 0, \quad i, j=1, \ldots, 5 .
$$

In order to analyze the accuracy of the forecast of expected portfolio return, the second method was chosen. The flow of payments for the sub-portfolio of consumer loans $(N \approx 40000)$, was forecasted. The calculations were based on data for January, $2014-$ December, 2015 (24 months), that is, in the period of relative instability of the financial market. The forecast was conducted for the period until June, 2016. The average interest rate on loans was $25 \%$, the contract period was 3 years, and discounting factor was equal to $8 \%$ per annum.

Based on the statistical data, the fluctuations in the observed migration coefficients (frequencies) $w_{i j}(t)$ were analyzed. On the basis of the analysis, a confidence set $\mathbb{P}_{1}$ is generated for the possible values of the elements of the transition probabilities matrix $P$. The transition probabilities estimates based on the data on transitions in 2016 fell into the obtained set.

Based on the data 2014-2015 and by the simple moving average method [13], the matrix of transition probabilities $\bar{P}=\left\{\bar{p}_{i j}\right\}$ was estimated and the set $\mathbb{P}$ of possible values of transition probabilities was calculated taking into account both the restrictions $(20)$ and the fact that some transitions are not carried out in the system, for example $p_{5 j}=0$, $j=1, \ldots, 4, p_{13}=0$. Using the matrix $\bar{P}$, the expected net present value of the portfolio $B(T, \bar{P})=\overline{N P V}(T)$ was forecasted for $T=36$ months by the formulas (12) - (14), (17), where the initial moment is January 2014. 
The calculations showed that the portfolio is unprofitable for the considered discounting rate $8 \%$ per annum: $\overline{N P V}(36)=-0,042 A$, where $A=A(0)$ is an amount of issued loans. Without discounting (for $r=0$ ), the expected return is $\overline{N P V}_{0}(T)=0,07 A$, which also can not be considered as a good indicator taking into account the inflation and the duration of the period, $T=36$ months.

In connection with the fluctuations in the transition probabilities, an analysis on sensitivity of $B(T, P)=\overline{N P V}(T)$ to relatively small changes in the transition probabilities was carried out. The calculations were carried out using the MathCad package for the calculated matrix of transition probabilities $\bar{P}$. Also, the influence of changes in the transition probabilities within the set $\mathbb{P}$ was studied.

The calculations show that for all matrices $P \in \mathbb{P}$ the restrictions $\left|p_{i j}-\bar{p}_{i j}\right| \leq 0,02$, $i, j=1, \ldots, k$ hold, and the greatest influence is given by the probabilities $p_{12}$ (for transition from the first group to the second one) and $p_{45}$ (for transition from the problem group to the "repaid loans" group), and, in the analyzed portfolio, the output from the problem group occurred mainly by cancellation. We obtain the following dependence that fairly accurate describes behavior of the expected net present value for $T=36$ with a change in the transition probabilities: $B(T, \bar{P}+\Delta P) \approx-0,042 A+\left(2,2 \Delta p_{45}-0,3 \Delta p_{12}\right) A$. Based on the analysis, we formulate the following recommendations: either strenuously work with the problem loans, or restructure the loan portfolio. These recommendations do not contradict the conclusions obtained in the department of risk analysis.

Note that the considered model of payment flows is a simplified model of a real process, because it does not take into account early payments of the loan part, which are random, as well as fines and penalties for late payments. These features may be taken into account in the further development of the model. In addition, for analysis, we choose a simplified scheme to devide the loan portfolio into groups, although usually banks use more groups. The construction of the model is primarily aimed at developing the method to describe the payment flow as a random process, depending on the simple Markov chain.

\section{Conclusion}

We propose the method to describe payment flows for the portfolio of homogeneous loans. We assume that a change in the portfolio structure is described by the discrete Markov chain. We obtain the mathematical model of net present value in the form of the multistep Markov process. The model can be refined and complicated for a more complete accounting of all payments on loans, including early cancellation of the debt part, payment of penalties and fines for delayed payments, etc.

The problem of forecasting the expected return from the issuance of loan is reduced to the problem of estimating the statistical moments of the Markov process. The proposed approach can be used to develop algorithms of forecasting the payment flows in the case of issuance of consumer loan, for estimating the numerical characteristics of the return $(N P V, I R R)$ in the conditions of incomplete information on transition probabilities, and also for obtaining mathematical methods to control the issuance of loan. 


\section{References}

1. Gupton G.M., Finger C.C., Bhatia M. CreditMetrics - Technical Document. N.Y., J.P. Morgan and Co., 1997.

2. Schuermann T. Credit Migration Matrices. Encyclopedia of Quantitative Risk Assessment, N.Y., John Wiley \& Sons, 2008. DOI: 10.1002/9780470061596.risk0409

3. Fantazzini D. [Credit Risk Management]. Applied Econometrics, 2008, vol. 4, no. 12, pp. 105-138. (in Russian)

4. Jones M.T. Estimating Markov Transition Matrices Using Proportions Data: An Application to Credit Risk. International Monetary Fund Working Paper, 2005, WP-05-219.

5. Jafry Y., Schuermann T. Measurement, Estimation and Comparison of Credit Migration Matrices. Journal of Banking and Finance, 2004, vol. 28, pp. 2603-2639. DOI: $10.1016 /$ j.jbankfin.2004.06.004

6. Anderson T.W., Goodman L.A. Statistical Inference about Markov Chains. Annals of Mathematical Statistics, 1957, vol. 28, pp. 89-110. DOI: 10.1214/aoms/1177707039

7. Kiefer N.M., Larson C.E. A Simulation Estimator for Testing the Time Homogeneity of Credit Rating Transitions. Journal of Empirical Finance, 2007, vol. 14, pp. 818-835. DOI: $10.1016 /$ j.jempfin.2006.08.001

8. Quirini L., Vannucci L. Creditworthiness Dynamics and Hidden Markov Models. Journal of the Operational Research Society, 2014, vol. 65, no. 3, pp. 323-330. DOI: 10.1057/jors.2012.181

9. Kaniovski Y.M., Pflug G.Ch. Risk Assessment for Credit Portfolios: A Coupled Markov Chain Model. Journal of Banking and Finance, 2007, vol. 31, pp. 2303-2323. DOI: $10.1016 /$ j.jbankfin.2007.02.005

10. Timofeeva G.A., Timofeev N.A. Forecasting Credit Portfolio Components with a Markov Chain Model. Automation and Remote Control, 2012, vol. 73, no. 4, pp. 637-651. DOI: $10.1134 /$ S0005117912040042

11. Thyagarajan V., Saiful M. Retail Banking Loan Portfolio Equilibrium Mix: A Markov Chain Model Analysis. American Journal of Applied Science, 2005, vol. 2, no. 1, pp. 410-419. DOI: 10.3844 /ajassp.2005.410.419

12. Zhuravel' Ju.Ju. [Topical Issues of Loan Portfolio Reservation]. Bankovskij Ritejl, 2007, no. 4, pp. 21-36. (in Russian)

13. Nasel'skiy S.P., Jakimenko D.V. Calculation of the Size of Retail Loan Portfolio Reserves of Commercial Bank. Vestnik Sankt-Peterburgskogo Universiteta Gosudarstvennoy Protivopozharnoy Sluzhy MChS Rossii, 2009, no. 2, pp. 139-143. (in Russian)

14. Bronshtein E.M. [Optimization of the Time Structure of an Investment Project]. Sibirskii zhurnal industlial'noi matematiki [Journal of Applied and Industrial Mathematics], 2005, vol. 8, no. 1, pp. 17-29. (in Russian)

15. de Andrade F.W.M., Thomas L. Structural Models in Consumer Credit. European Journal of Operational Research, 2007, vol. 183, pp. 1569-1581. DOI: 10.1016/j.ejor.2006.07.049

16. Kurzhanskii A.B., Furasov V.D. Identification of Bilinear Systems. Guaranteed Pseudoellipsoidal Estimates. Automation and Remote Control, 2000, vol. 61, no. 1, pp. 38-49.

17. Zav'yalova T.V., Kats I.Ya., Timofeeva G.A. Stochastic System with a Ramdom Jump in Phase Trajectoty: Stability of Their Motion. Automation and Remote Control, 2002, vol. 63, no. 7, pp. 1070-1079. DOI: 10.1023/A:1016102730151

18. Nikonov O.I., Timofeev N.A. [Cash Flows of the Loan Portfolio under Condition of Uncertainty]. Bulletin of Ural Federal University. Series: Economics and Management, 2013, no. 2, pp. 106-111. (in Russian) 
19. Timofeev N., Timofeeva G. Estimation of Loan Portfolio Risk on the Basis of Markov Chain Model. IFIP Advances in Information and Communication Technology, 2013, vol. 391, Springer, pp. 207-216.

Received January 25, 2017

УДК 519.217

DOI: $10.14529 / \mathrm{mmp} 170305$

\title{
ПРОГНОЗИРОВАНИЕ ДОХОДНОСТИ КРЕДИТНОГО ПОРТФЕЛЯ НА ОСНОВЕ МАРКОВСКОЙ МОДЕЛИ
}

Г.A. Tuмофеева, Уральский государственный университет путей сообщения, г. Екатеринбург

\begin{abstract}
Рассматривается задача математического моделирования потоков платежей кредитного портфеля. Предполагается, что изменение качества каждого отдельного кредита описывается простой марковской цепью с конечным числом состояний. Поток платежей по кредиту при таком рассмотрении представляет случайный процесс, зависящий от марковской цепи. На основе предложенной модели и известных соотношений теории стохастических систем получено описание ожидаемых потоков платежей всего кредитного портфеля, построен метод прогнозирования ожидаемого дохода (чистой приведенной стоимости) портфеля. Проанализирована точность полученной модели, проведен анализ чувствительности чистой приведенной стоимости портфеля к изменению переходных вероятностей в марковской цепи.
\end{abstract}

Ключевые слова: потоки платежей; марковская цепь; кредитный портфель; прогнозирование.

\section{Литература}

1. Gupton, G.M. CreditMetrics - Technical Document / G.M. Gupton, C.C. Finger, M. Bhatia. - N.Y.: J.P. Morgan and Co., 1997.

2. Schuermann, T. Credit Migration Matrices / T. Schuermann // Encyclopedia of Quantitative Risk Assessment. - N.Y.: John Wiley \& Sons, 2008.

3. Фантаццини, Д. Управление кредитным риском / Д. Фантаццини //Прикладная эконометрика. - 2008. - Т. 4, № 12. - С. 105-138.

4. Jones, M.T. Estimating Markov Transition Matrices Using Proportions Data: An Application to Credit Risk // International Monetary Fund Working Paper. - 2005. - WP-05-219.

5. Jafry, Y. Measurement, Estimation and Comparison of Credit Migration Matrices / Y. Jafry, T. Schuermann // Journal of Banking \& Finance. - 2004. - V. 28. - P. 2603-2639.

6. Anderson, T.W. Statistical Inference about Markov Chains / T.W. Anderson, L.A. Goodman // Annals of Mathematical Statistics. - 1957. - V. 28. - P. 89-110.

7. Kiefer, N.M. A Simulation Estimator for Testing the Time Homogeneity of Credit Rating Transitions / N.M. Kiefer, C.E. Larson // Journal of Empirical Finance. - 2007. - V. 14. P. $818-835$.

8. Quirini, L. Creditworthiness Dynamics and Hidden Markov Models / L. Quirini, L. Vannucci // Journal of the Operational Research Society. - 2014. - V. 65, № 3. - P. 323-330.

9. Kaniovski, Y.M. Risk Assessment for Credit Portfolios: A Coupled Markov Chain Model / Y.M. Kaniovski, G.Ch. Pflug // Journal of Banking \& Finance. - 2007. - V. 31. P. 2303-2323.

Вестник ЮУрГУ. Серия «Математическое моделирование

и программирование» (Вестник ЮУрГУ ММП). 2017. Т. 10, № 3. С. 54-66 
10. Тимофеева, Г.А. Прогнозирование составляющих кредитного портфеля на основе модели марковской цепи / Г.А. Тимофеева, Н.А. Тимофеев // Автоматика и телемеханика. 2012. - № 4. - C. 47-65.

11. Thyagarajan, V. Retail Banking Loan Portfolio Equilibrium Mix: A Markov Chain Model Analysis / V. Thyagarajan, M. Saiful // American Journal of Applied Science. - 2005. - V. 2, № 1. - P. 410-419.

12. Журавель, Ю.Ю. Актуальные вопросы резервирования розничного кредитного портфеля / Ю.Ю. Журавель // Банковский ритейл. - 2007. - № 4. - С. 21-36.

13. Насельский, С.П. Расчет размера резервов розничного кредитного портфеля коммерческого банка / С.П. Насельский, Д.В. Якименко / Вестник Санкт-Петербургского университета Государственной противопожарной службы МЧС России. - 2009. - № 2. C. $139-143$.

14. Бронштейн, Е.М. Оптимизация временной структуры инвестиционного проекта / Е.М. Бронштейн // Сибирский журнал индустриальной математики. - 2005. - Т. 8, № 1. - C. 17-29.

15. Andrade, F.W. Structural Models in Consumer Credit / F.W.M. de Andrade, L. Thomas // European Journal of Operational Research. - 2007. - V. 183. - P. 1569-1581.

16. Куржанский, А.Б. Идентификация билинейных систем. Гарантированные псевдоэллипсоидальные оценки / А.Б. Куржанский, В.Д. Фурасов // Автоматика и телемеханика. 2000. - № 1. - C. 41-53.

17. Завьялова, Т.В. Об устойчивости движения стохастических систем со случайным условием скачка фазовой траектории / Т.В. Завьялова, И.Я. Кац, Г.А. Тимофеева // Автоматика и телемеханика. - 2002. - № 7. - С. 33-43.

18. Никонов, О.И. Потоки платежей кредитного портфеля в условиях неполной статистической информации / О.И. Никонов, Н.А. Тимофеев // Вестник УрФУ. Серия: Экономика и управление. - 2013. - № 2. - С. 106-111.

19. Timofeev, N. Estimation of Loan Portfolio Risk on the Basis of Markov Chain Model / N. Timofeev, G. Timofeeva // IFIP Advances in Information and Communication Technology. Vol. 391: System Modeling and Optimization. IFIP TC7 Conference: CSMO 2011. - Springer, 2013. - P. 207-216.

Галина Адольфовна Тимофеева, доктор физико-математических наук, профессор, кафедра «Естественнонаучные дисциплины», Уральский государственный университет путей сообщения (г. Екатеринбург, Российская Федерация), Gtimofeeva@usurt.ru.

Поступила в редакиию 25 января 2017 г. 